\title{
Effects of calcium on emergence and seedling growth of castor bean under salinity stress
}

\author{
Xiaoqian Guo ${ }^{1,2}$, Guisheng Zhou ${ }^{1,2, *}$, Guanglong $\mathrm{Zhu}^{2}$ and Xiurong $\mathrm{Jiao}^{2}$ \\ ${ }^{1}$ Key Laboratory of Crop Genetics and Physiology of Jiangsu Province, Yangzhou University, Yangzhou 225009, Jiangsu Province, China \\ ${ }^{2}$ Joint International Research Laboratory of Agriculture and Agri-Product Safety of Ministry of Education of China, Yangzhou University, \\ Yangzhou 225009, China
}

\begin{abstract}
A growth chamber study was conducted to assess the interactive effects of salinity and $\mathrm{Ca}^{2+}$ amendment on the emergence and early seedling growth of castor bean (Ricinus communis L.). Seedlings were cultured in wet sands filled with one-half Hoagland solution containing salts either at 0,50 or $100 \mathrm{mM} \mathrm{NaCl}$. Supplemental $\mathrm{Ca}^{2+}$ was added at molar mass ratio of $\mathrm{NaCl}$ and $\mathrm{CaCl}_{2}$ of $20: 0,20: 1,20: 2$ and $20: 3$. Increasing salinity level reduced emergence rate, height and leaf area by up to $34.0 \%, 26.1 \%$ and 46.0\% respectively. Calcium amendment increased emergence, height, leaf area, dry plant weight, chlorophyll $a, b$, chlorophyll $(a+b)$ and soluble protein by up to $22.1 \%, 13.7 \%, 21.3 \%, 30.3 \%, 28.6 \%, 24.0 \%$, $25.8 \%$ and $42.4 \%$ respectively. The present study indicates that the negative effects of salinity on emergence and early seedling growth of castor bean could be lessened with exogenous application of $\mathrm{Ca}^{2+}$ at appropriate concentrations.
\end{abstract}

Keywords: Calcium application, castor bean plant, emergence, growth, salinity.

SALINITY is one of the major environmental stresses that limits plant growth and productivity in the world, especially in areas where the soil contains medium to high salt concentration and the evaporative demand is high ${ }^{1-4}$. Planting of salt-tolerant crops is a possible strategy to combat salt stress and improve crop productivity in these regions ${ }^{5}$.

Castor bean (Ricinus communis L.), used in coatings, greases, industrial surfactants and pharmaceutical and cosmetic products, is an economically feasible option for soils at medium to high salinity levels. It has been proven to have low to moderate salt tolerance and the threshold level of salt was found to be $7.1 \mathrm{dS} \mathrm{m}^{-1}$ (refs 6, 7). Its production is therefore being considered in soils where salinity poses a threat to the production of conventional crops such as rice (Oryza sativa L.) ${ }^{8}$, bean (Phaseolus vulgaris L.) ${ }^{9}$ and tomato (Lycopersicon esculentum $)^{10}$.

Although castor bean is salt-tolerant, some studies have suggested that germination and early seedling growth are seriously inhibited when salt content in the growing medium is high ${ }^{11}$. Zhou et al. ${ }^{6}$ reported that the

\footnotetext{
*For correspondence. (e-mail: gszhou@yzu.edu.cn)
}

emergence and survival rates decreased to below $70 \%$ and $50 \%$ respectively, as soil salinity level increased to $10.4 \mathrm{dS} \mathrm{m}^{-1}$ (ref. 6). Hence new strategies are needed to mitigate the adverse effects of salinity on the emergence and early seedling growth of castor bean.

Physiologically, the adverse effects of salinity on crop germination, growth, and biochemical and physiological processes can be summarized as ion toxicity, osmotic stress, mineral deficiency, ion imbalance, biochemical and physiological disturbances, or their combinations ${ }^{2}$. These effects are a function of not only the total salt concentration, but also of the $\mathrm{Na}^{+}: \mathrm{Ca}^{2+}$ ratio in growth medium. Crops grown in saline soils generally require more calcium than those grown in non-saline soils, because calcium concentration that is sufficient in nonsaline soils may become nutritionally insufficient under saline conditions with high $\mathrm{Na}: \mathrm{Ca}$ ratios $^{12}$. Calcium amendment of irrigation water or saline soil has therefore been suggested as a possible approach to mitigating the effects of salinity on crop productivity under saline conditions $^{13,14}$

Calcium plays a vital role in protecting crops by stabilizing the structure of plant cell walls, maintaining the structural and functional integrity of plant membranes, regulating the selectivity and transport of ions, and controlling ion-exchange as well as enzyme activities ${ }^{15,16}$. Under saline condition, increased $\mathrm{Ca}^{2+}$ levels can protect plants from $\mathrm{Na}^{+}$toxicity through increasing $\mathrm{K}^{+}$uptake and improving the $\mathrm{K}^{+}: \mathrm{Ca}^{2+}$ ratio, decreasing the displacement of membrane-related $\mathrm{Ca}^{2+}$, decreasing the uptake and transport of $\mathrm{Na}^{+}$to shoots, and improving the content of soluble sugar and soluble protein ${ }^{17-19}$. Maintaining adequate supply of calcium under saline condition is a critical factor in controlling the severity of a particular ion toxicity, especially in crops which are susceptible to $\mathrm{Na}$ damage ${ }^{17}$. The beneficial effects of an external amendment of $\mathrm{Ca}^{2+}$ in saline soils have been reported for the production of various crop species such as wheat ${ }^{20}$, maize (Zea mays L.) ${ }^{21}$, sweet sorghum (Sorghum saccharatum M.) ${ }^{13}$, tomato $^{10}$, strawberry (Fragaria ananassa D. $)^{22}$ and potato (Solanum tuberosum L.) $)^{23}$. However, little information is available regarding the effects of calcium amendment on the crucial emergence and early growth stages of seedlings. External $\mathrm{Ca}^{2+}$ amendment to 
growing medium might be a possible way to improve emergence and early seedling growth of castor bean. With this in mind, we proposed to evaluate the usefulness of calcium amendments with a range of $\mathrm{Na}^{+}: \mathrm{Ca}^{2+}$ ratios, in alleviating the adverse effects of salinity on the germination, emergence and seedling growth of castor bean. This knowledge is useful for understanding the $\mathrm{Na}^{+}: \mathrm{Ca}^{2+}$ interplays for this crop species at the whole plant level.

The objectives of the present study are to (i) measure the effects of external calcium amendment on emergence, seedling growth and physiological parameters of castor bean under saline conditions, and (ii) recommend a suitable $\mathrm{Na}^{+}: \mathrm{Ca}^{2+}$ ratio that would maximum benefit castor bean plants during emergence and seedling growth.

\section{Materials and methods}

\section{Materials and experimental design}

A growth chamber study was conducted in the Joint International Research Laboratory of Agriculture and Agri-Product Safety of the Ministry of Education of China, Yangzhou University $\left(32^{\circ} 30^{\prime} \mathrm{N}, 119^{\circ} 25^{\prime} \mathrm{E}\right)$, Jiangsu Province, China. The seeds of Zibi 5, which is a widely extended variety in China, were kindly provided by Zibo Academy of Agricultural Science and Technology, Shandong Province, China, and used in this study. Also, wet fine sand was used as the sowing substrate. Before the study, the sand was rinsed with tap water until the water was clean. The sand was again washed with deionized water and dried in a dryer at $100^{\circ} \mathrm{C}$ for $24 \mathrm{~h}$. Plastic trays, of dimension $50 \times 30 \times 5 \mathrm{~cm}$ (length $\times$ width $\times$ height) each and containing 54 cells $(2.5 \mathrm{~cm}$ deep, 5.0 and $2.5 \mathrm{~cm}$ upper and bottom diameter per cell), were used for seed germination and seedling development. The growth medium in the study was similar to one-half Hoagland solution, but without $\mathrm{Ca}(\mathrm{NO})_{3}$. Compared with the whole Hoagland solution, only half amount of all the chemicals was dissolved in the water.

In this study, a completely randomized design of $3 \times 4$ factors with three replicates was used. The two experimental factors were salinity (sodium chloride, $\mathrm{NaCl}$ ) level and molar mass ratio of sodium chloride to calcium chloride $\left(\mathrm{CaCl}_{2}\right)$. The $\mathrm{NaCl}$ level included 0,50 and $100 \mathrm{mM}$ (referred to as $\mathrm{A} 1, \mathrm{~A} 2$ and $\mathrm{A} 3$ respectively). The $\mathrm{NaCl} / \mathrm{CaCl}_{2}$ molar mass ratio included $20: 0,20: 1,20: 2$ and $20: 3$ (referred to as B1, B2, B3 and B4 respectively). Both $\mathrm{NaCl}$ and $\mathrm{CaCl}_{2}$ at appropriate amounts were dissolved in the $\mathrm{Ca}\left(\mathrm{NO}_{3}\right)_{2}$-free one-half Hoagland solution for each treatment.

\section{Seed germination and seedling development}

On the day of seeding, castor bean seeds of uniform size were selected and soaked for $15 \mathrm{~min}$ in warm distilled water $\left(75^{\circ} \mathrm{C}\right)$ to maximize the germination potential. At the same time, wet fine sand was filled in 48 plastic trays (four trays per treatment, one tray as a replicate for each treatment) at $2.5 \mathrm{~kg}$ per tray and softly packed. Each tray was then sown with one castor seed per cell at a depth of $1 \mathrm{~cm}$. After seeding, all plastic trays were placed in stainless steel trays $(50 \times 30 \times 5 \mathrm{~cm}$ each in length, width and height) and filled with one-half Hoagland solution for each treatment. All plastic trays were placed in well-lit growth chambers for 30 days (model PYX-300G-B, Yangzhou Yiwei Automatic Instrument Co, Ltd, Jiangsu Province, China). The growth chambers were maintained at a temperature regime of $30^{\circ} \mathrm{C} / 25^{\circ} \mathrm{C}$ (day/night) with a photoperiod of $14 \mathrm{~h}$ as well as light intensity of $500 \mu \mathrm{mol} \mathrm{m} \mathrm{m}^{-2} \mathrm{~s}^{-1}$. The relative humidity was maintained at $70 \%$. The same amount of deionized water was added to each plastic tray to prevent moisture stress in the chambers. The one-half $\mathrm{Ca}\left(\mathrm{NO}_{3}\right)_{2}$-free Hoagland solution for each treatment was replaced every 5 days.

\section{Observations and measurements}

On the 20th day after seeding, the number of seedlings in each plastic tray was counted, and the final emergence rate was calculated as the percentage of number of seedlings in the total sown seeds. On the 33 rd day after seeding, 20 seedlings of each replicate of each treatment were marked non-destructively and the plant height was measured (from the level at which the cotyledons were attached to the top of stem) when the second leaf appeared in the control treatment. On the 38th day after seeding, when in the control treatment the second leaf expanded, ten tagged plants for each replicate of each treatment were harvested and recorded for leaf area using a leaf area meter (model Li-3000A, LI-COR, Inc, Lincoln, NE, USA). The plants were then ovendried at $80^{\circ} \mathrm{C}$ to constant weight to determine biomass. The other ten marked plants were harvested and leaves of these plants were sampled, washed carefully with deionized water, soaked in liquid nitrogen and then stored in a low-temperature freezer $\left(-80^{\circ} \mathrm{C}\right)$ for determination of soluble protein, chlorophyll, soluble sugar and proline.

Leaf chlorophyll content (chlorophyll $a, b$ and $a+b$ ) was determined using the method of Wintermans and De Mots $^{24}$. Around $0.1 \mathrm{~g}$ of leaf sample was cut into small pieces and soaked for $72 \mathrm{~h}$ in $10 \mathrm{ml}$ absolute ethanol. Absorbance readings of the solutions were recorded at 665 and $649 \mathrm{~nm}$ respectively. The concentrations of chlorophyll $a, b$ and $a+b$ were calculated according to the following formulae:

$$
\begin{aligned}
& \text { Chlorophyll } a\left(\mathrm{mg} \mathrm{g}^{-1} \mathrm{FW}\right)=\left(13.70 \mathrm{~A}_{665}-5.76 A_{649}\right) \\
& \quad \times 10 /(1000 \times W) \times V
\end{aligned}
$$




$$
\begin{aligned}
& \text { Chlorophyll } b\left(\mathrm{mg} \mathrm{g}^{-1} \mathrm{FW}\right)=\left(25.8 A_{649}-7.60 A_{665}\right) \\
& \quad \times 10 /(1000 \times W) \times V \\
& \text { Chlorophyll } a+b\left(\mathrm{mg} \mathrm{g}^{-1} \mathrm{FW}\right)=\text { Chlorophyll } a \\
& \quad+\text { chlorophyll } b,
\end{aligned}
$$

where $V$ is the volume of sample solution $(\mathrm{ml}), A$ the absorbance and $W$ is the fresh weight of sample $(\mathrm{g})$.

Soluble sugar content was determined by the method of Haslemore and Roughan ${ }^{25}$. Plant material (100 mg) was abstracted with $10 \mathrm{ml} 62.5 \%$ methanol at $55^{\circ} \mathrm{C}$ for $15 \mathrm{~min}$ using screw-capped culture tubes $(16 \times 125 \mathrm{~mm})$. The samples were cooled and centrifuged, and then $4 \mathrm{ml}$ aliquots were transmitted to a second series of capped culture tubes, with each tube containing $0.1 \mathrm{ml}$ saturated lead acetate. Standards were prepared by diluting $0.5,1.0$ and $1.5 \mathrm{ml}$ sucrose standard solution to $10 \mathrm{ml}$ with $62.5 \%$ methanol. The aliquots $(4 \mathrm{ml})$ were removed and treated in the same way as the unknowns to give standards equivalent to $5 \%, 10 \%$ and $15 \%$ soluble sugar respectively, on a dry weight basis. After standing for $10 \mathrm{~min}$ with shaking occasionally, $5 \mathrm{ml}$ chloroform was added and then the tubes were capped and vigorously shaken. They were centrifuged for a short time to aid phase separation. Aliquots $(50 \mu \mathrm{l})$ were taken from the upper aqueous phase, and $1 \mathrm{ml} \mathrm{5 \%}$ phenol and $4 \mathrm{ml}$ sulphuric acid were added to this. The samples were cooled to room temperature and absorbance was read at $490 \mathrm{~nm}$.

Approximately $0.5 \mathrm{~g}$ of fresh leaf samples was used to extract and analyse soluble protein. The samples were homogenized in $5 \mathrm{ml}$ cold water (Milli-Q reagent grade) at $4{ }^{\circ} \mathrm{C}$ and centrifuged for $5 \mathrm{~min}$ at $800 \mathrm{~g}$. The supernatant was stored on ice. The pellet was suspended in $3 \mathrm{ml}$ cold water and then recentrifuged $(800 \mathrm{~g})$ for $5 \mathrm{~min}$. The supernatants were pooled and stored on ice for the following analysis. One aliquot was taken to determine soluble protein using the Coomassie Blue dye-binding assay $^{26}$. Absorbance readings were converted using bovine serum albumin (BSA) as the protein standard.

The proline content was measured according to the method of Bates et ll. $^{27}$. Around $0.5 \mathrm{~g}$ of leaf sample was homogenized in $10 \mathrm{ml} \mathrm{3 \%}$ aqueous sulphosalicylic acid and then the homogenate was centrifuged for $20 \mathrm{~min}$ at $3000 \mathrm{~g}$. The supernatant was used to estimate the proline concentration. The reaction mixture consisted of $2 \mathrm{ml}$ glacial acetic acid and $2 \mathrm{ml}$ acid-ninhydrin, which was boiled for $1 \mathrm{~h}$ at $100^{\circ} \mathrm{C}$. After quenching the reaction in an ice bath, the reaction mixture was extracted with $4 \mathrm{ml}$ toluene and absorbance was read at $520 \mathrm{~nm}$.

\section{Statistical analyses}

The average values at a sampling date across all the plants were calculated within a replicate for each treat- ment. Then, according to the two-factor completely randomized design, the data were subjected to analysis of variance (ANOVA) using the statistical package DPS 7.05 for Windows ${ }^{28}$. If ANOVA reported significant differences, treatment mean differences were separated by Tukey's honest significant difference (Tukey's HSD) test.

\section{Results}

The results of ANOVA showed that salinity, calcium and their interaction had significant effects on all the growth and physiological parameters of castor bean (Table 1).

\section{Effects of salinity on growth and physiological parameters}

When compared with $0 \mathrm{mM} \mathrm{NaCl}$ level, emergence, plant height, leaf area, dry plant weight, the chlorophyll $a, b$, and $a+b$ content and soluble protein were reduced at both 50 and $100 \mathrm{mM} \mathrm{NaCl}$ levels. This reduction in measured parameters was much greater for increase in salinity from 50 to $100 \mathrm{mM} \mathrm{NaCl}$ than that from 0 to $50 \mathrm{mM} \mathrm{NaCl}$ (Table 2). The content of soluble sugar did not decrease at $50 \mathrm{mM} \mathrm{NaCl}$, but reduced at the $100 \mathrm{mM}$ $\mathrm{NaCl}$ level. Proline content increased by $45.6 \%$ and $67.0 \%$ at 50 and $100 \mathrm{mM} \mathrm{NaCl}$ level respectively (Table 2).

\section{Effects of calcium amendment on growth and physiological parameters}

When measurements were averaged over the entire salinity levels, all the measured parameters improved by one or more molar ratios of calcium amendment, although the magnitude of increase and molar ratio providing the largest increase varied according to the parameter (Table 3). With the exception of dry plant weight, plant height and proline, the amendment of $20: 2 \mathrm{Na}^{+}: \mathrm{Ca}^{2+}$ provided better beneficial effects compared with the other molar ratios. The higher molar ratio of $20: 3$ provided the largest increase in plant height and proline content, while the smallest molar ratio of $20: 1$ provided the largest increase in dry plant weight. The contents of soluble protein and proline showed the largest percentage increase with calcium amendment (42.4\% and $72.3 \%$ respectively), although all other growth and physiological parameters were also increased $(P<0.05$; Table 3$)$.

\section{Interactive effects of salinity and calcium amendment on growth and physiological parameters}

At all the three salinity levels, growth and physiological parameters were increased to different degrees by 
Table 1. ANOVA of the effects of salinity and calcium amendment on growth and physiological parameters of castor bean

\begin{tabular}{|c|c|c|c|c|c|c|}
\hline \multirow[b]{3}{*}{ Dependent variable } & \multicolumn{6}{|c|}{ Independent variable } \\
\hline & \multicolumn{2}{|c|}{ Salinity } & \multicolumn{2}{|c|}{ Calcium } & \multicolumn{2}{|c|}{ Salinity $\times$ calcium } \\
\hline & $\mathrm{d} f$ & $F$-value & $\mathrm{d} f$ & $F$-value & $\mathrm{d} f$ & $F$-value \\
\hline Emergence (\%) & 2 & $1752.46^{* *}$ & 3 & $236.23 * *$ & 6 & $50.79 * *$ \\
\hline Plant height (cm) & 2 & $1277.35 * *$ & 3 & $121.50 * *$ & 6 & $19.56^{* *}$ \\
\hline Leaf area $\left(\mathrm{cm}^{2}\right)$ & 2 & $1502.03 * *$ & 3 & $101.67 * *$ & 6 & $9.47 * *$ \\
\hline Dry plant weight (g) & 2 & $1809.33 * *$ & 3 & $148.68 * *$ & 6 & $33.82 * *$ \\
\hline Chlorophyll $a\left(\mathrm{mg} \mathrm{g}^{-1} \mathrm{FW}\right)$ & 2 & $447.45^{* *}$ & 3 & $192.31 * *$ & 6 & $89.10 * *$ \\
\hline Chlorophyll $b$ ( $\left.\mathrm{mg} \mathrm{g}^{-1} \mathrm{FW}\right)$ & 2 & $21.44 * *$ & 3 & $34.53 *$ & 6 & $3.59 * *$ \\
\hline Chlorophyll $a+b\left(\mathrm{mg} \mathrm{g}^{-1} \mathrm{FW}\right)$ & 2 & $3.15^{*}$ & 3 & $0.22 * *$ & 6 & $0.70 * *$ \\
\hline Soluble protein $\left(\mathrm{mg} \mathrm{g}^{-1} \mathrm{FW}\right)$ & 2 & $471.11 * *$ & 3 & $174.4 * *$ & 6 & $3.23 *$ \\
\hline Soluble sugar (\%) & 2 & $207.47 * *$ & 3 & $16.27 * *$ & 6 & $7.46 * *$ \\
\hline Proline $\left(\mu \mathrm{g} \mathrm{g}^{-1} \mathrm{FW}\right)$ & 2 & $740.84 * *$ & 3 & $260.60 * *$ & 6 & $33.85 * *$ \\
\hline
\end{tabular}

$* * P<0.01 ; * P<0.05 ;$ n.s. insignificant difference. For each measured parameter, the degree of freedom between blocks is 2 and the degree of freedom for errors is 22 .

Table 2. Growth and physiological parameters as influenced by salinity level

\begin{tabular}{lccc}
\hline & \multicolumn{3}{c}{ Salinity level $(\mathrm{mM} \mathrm{NaCl})$} \\
\cline { 2 - 4 } Parameter & 0 & 50 & 100 \\
\hline Emergence $(\%)$ & $90.6 \mathrm{a}$ & $85.6 \mathrm{~b}$ & $59.8 \mathrm{c}$ \\
Plant height $(\mathrm{cm})$ & $8.8 \mathrm{a}$ & $8.1 \mathrm{~b}$ & $6.5 \mathrm{c}$ \\
Leaf area $\left(\mathrm{cm}^{2}\right)$ & $33.5 \mathrm{a}$ & $30.0 \mathrm{~b}$ & $18.1 \mathrm{c}$ \\
Dry plant weight $(\mathrm{g})$ & $1.28 \mathrm{a}$ & $1.21 \mathrm{~b}$ & $0.64 \mathrm{c}$ \\
Chlorophyll $a\left(\mathrm{mg} \mathrm{g}^{-1} \mathrm{FW}\right)$ & $1.8 \mathrm{a}$ & $1.74 \mathrm{~b}$ & $1.39 \mathrm{c}$ \\
Chlorophyll $b\left(\mathrm{mg} \mathrm{g}^{-1} \mathrm{FW}\right)$ & $0.59 \mathrm{a}$ & $0.55 \mathrm{~b}$ & $0.50 \mathrm{c}$ \\
Chlorophyll $a+b\left(\mathrm{mg} \mathrm{g}^{-1} \mathrm{FW}\right)$ & $2.4 \mathrm{a}$ & $2.2 \mathrm{~b}$ & $1.9 \mathrm{c}$ \\
Soluble protein $\left(\mathrm{mg} \mathrm{g}^{-1} \mathrm{FW}\right)$ & $21.9 \mathrm{a}$ & $19.0 \mathrm{~b}$ & $14.1 \mathrm{c}$ \\
Soluble sugar $(\%)$ & $3.4 \mathrm{a}$ & $3.4 \mathrm{a}$ & $2.2 \mathrm{~b}$ \\
Proline $\left(\mu \mathrm{g} \cdot \mathrm{g}^{-1} \mathrm{FW}\right)$ & $45.4 \mathrm{c}$ & $66.1 \mathrm{~b}$ & $75.8 \mathrm{a}$ \\
\hline
\end{tabular}

Within each row, the data followed by different letters are statistically different at the 0.05 probability level.

calcium amendment (Table 4; Figures 1 and 2). Although the $20: 2 \mathrm{Na}^{+}: \mathrm{Ca}^{2+}$ amendment showed best overall benefit for most growth and physiological parameters, further analysis is required to examine how these growth and physiological measurements made at different salinity levels respond to molar mass ratios in the amendment.

When individual salinity levels were analysed, all the three calcium amendment treatments benefited one or more growth and physiological parameters. At all the salinity levels, the highest leaf area and chlorophyll $a+b$ were observed with the $20: 2$ amendment, whereas the highest plant height and proline were observed with the $20: 3$ amendment (Table 4; Figures 1 and 2). There was no consistent response of other growth and physiological parameters to a particular molar ratio, and no consistent indication that a higher molar ratio improved parameters at the higher salinity level. The 20:2 amendment provided the largest increase in emergence, dry plant weight, chlorophyll $a$ and soluble sugar at $0 \mathrm{mM} \mathrm{NaCl}$ salinity level; chlorophyll $a$ and $b$ at $50 \mathrm{mM} \mathrm{NaCl}$ salinity level; and chlorophyll $b$ at $100 \mathrm{mM} \mathrm{NaCl}$ salinity level. The 20:1 amendment provided the largest increase in chlorophyll $b$ at the $0 \mathrm{mM} \mathrm{NaCl}$ salinity level; dry plant weight and soluble sugar at $50 \mathrm{mM} \mathrm{NaCl}$ salinity level, and emergence at $100 \mathrm{mM} \mathrm{NaCl}$ salinity level. The $20: 3$ amendment resulted in the highest emergence at $50 \mathrm{mM}$ $\mathrm{NaCl}$ salinity level, and the highest dry plant weight and chlorophyll $a$ at $100 \mathrm{mM} \mathrm{NaCl}$ salinity level (Table 4, Figures 1 and 2).

\section{Discussion}

In the absence of calcium amendment, parameters measuring emergence and early seedling growth of castor bean were reduced significantly by salinity. The content of soluble sugar was only reduced at the $100 \mathrm{mM} \mathrm{NaCl}$ level. The proline content increased significantly at both 50 and $100 \mathrm{mM} \mathrm{NaCl}$ levels (Table 3).

In the present study emergence was significantly inhibited by increased salinity, similar to the findings of our previous study ${ }^{6}$. The only difference was that the emergence of castor bean in the present study was lower than that at the same salinity level in the previous study. This difference might result from the different genetic backgrounds of the cultivars and difference in the growing media. In the present study, sand containing one-half Hoagland solution without $\mathrm{Ca}\left(\mathrm{NO}_{3}\right)_{2}$ was the growing medium, while in the previous study a mixture of conventional soil and organic substrate was used. Salt stress can affect the process of germination and the following emergence. In salt stress conditions, the hydrolytic action of starch, protein, and lipids, and the activities of many enzymes can be reduced, making it difficult for the seeds to germinate and emerge $e^{29,30}$. 
Table 3. Growth and physiological parameters as influenced by calcium amendment in seeding medium

\begin{tabular}{|c|c|c|c|c|}
\hline \multirow[b]{2}{*}{ Parameters } & \multicolumn{4}{|c|}{ Calcium amendment } \\
\hline & $20: 0$ & $20: 1$ & $20: 2$ & $20: 3$ \\
\hline \multicolumn{5}{|l|}{$\mathrm{Na}: \mathrm{Ca}$ ratio } \\
\hline Emergence (\%) & $68.3 b$ & $82.2 \mathrm{a}$ & $80.7 \mathrm{a}$ & $83.4 \mathrm{a}$ \\
\hline Plant height $(\mathrm{cm})$ & $7.3 \mathrm{~d}$ & $7.8 \mathrm{~b}$ & $7.7 \mathrm{c}$ & $8.3 \mathrm{a}$ \\
\hline Leaf area $\left(\mathrm{cm}^{2}\right)$ & $25.3 \mathrm{c}$ & $26.1 \mathrm{~b}$ & $30.7 \mathrm{a}$ & $26.7 \mathrm{~b}$ \\
\hline Dry plant weight $(\mathrm{g})$ & $0.89 \mathrm{~d}$ & $1.16 \mathrm{a}$ & $1.11 \mathrm{~b}$ & $1.01 \mathrm{c}$ \\
\hline Chlorophyll $a\left(\mathrm{mg} \mathrm{g}^{-1} \mathrm{FW}\right)$ & $1.4 \mathrm{c}$ & $1.7 \mathrm{~b}$ & $1.8 \mathrm{a}$ & $1.7 \mathrm{~b}$ \\
\hline Chlorophyll $b\left(\mathrm{mg} \mathrm{g}^{-1} \mathrm{FW}\right)$ & $0.50 \mathrm{~b}$ & $0.62 \mathrm{a}$ & $0.59 \mathrm{a}$ & $0.49 \mathrm{~b}$ \\
\hline Chlorophyll $a+b\left(\mathrm{mg} \mathrm{g}^{-1} \mathrm{FW}\right)$ & $1.9 \mathrm{~d}$ & $2.32 b$ & $2.39 \mathrm{a}$ & $2.19 \mathrm{c}$ \\
\hline Soluble protein $\left(\mathrm{mg} \mathrm{g}^{-1} \mathrm{FW}\right)$ & $14.4 \mathrm{c}$ & $18.3 \mathrm{~b}$ & $20.1 \mathrm{a}$ & $20.5 a$ \\
\hline Soluble sugar $(\%)$ & $3.1 \mathrm{a}$ & $3.2 \mathrm{a}$ & $3.1 \mathrm{a}$ & $2.7 \mathrm{~b}$ \\
\hline Proline $\left(\mu \mathrm{g} \mathrm{g}^{-1} \mathrm{FW}\right)$ & $54.2 \mathrm{~d}$ & $73.3 c$ & $82.2 b$ & $93.4 \mathrm{a}$ \\
\hline
\end{tabular}

Within each row, the data followed by different letters are statistically different at the 0.05 probability level.

Table 4. Growth parameters of castor seedlings as influenced by different levels of salinity and external calcium amendment

\begin{tabular}{llccc}
\hline Treatment* & $\begin{array}{c}\text { Emergence } \\
\text { (percentage) }\end{array}$ & $\begin{array}{c}\text { Plant height } \\
(\mathrm{cm})\end{array}$ & $\begin{array}{c}\text { Leaf area } \\
\mathrm{cm}^{2}\left(\text { plant }^{-1}\right)\end{array}$ & $\begin{array}{c}\text { Dry plant weight } \\
\left(\mathrm{g} \mathrm{plant}^{-1}\right)\end{array}$ \\
\hline A1B1* & $87.7 \pm 1.07 \mathrm{c}$ & $8.3 \pm 0.09 \mathrm{c}$ & $31.9 \pm 0.61 \mathrm{c}$ & $1.11 \pm 0.01 \mathrm{~d}$ \\
A1B2 & $89.1 \pm 1.27 \mathrm{bc}$ & $8.8 \pm 0.09 \mathrm{~b}$ & $33.3 \pm 0.63 \mathrm{~b}$ & $1.42 \pm 0.02 \mathrm{a}$ \\
A1B3 & $91.8 \pm 0.63 \mathrm{a}$ & $8.7 \pm 0.09 \mathrm{~b}$ & $35.5 \pm 0.57 \mathrm{a}$ & $1.40 \pm 0.05 \mathrm{a}$ \\
A1B4 & $93.6 \pm 0.81 \mathrm{a}$ & $9.2 \pm 0.05 \mathrm{a}$ & $33.2 \pm 0.79 \mathrm{bc}$ & $1.20 \pm 0.02 \mathrm{c}$ \\
A2B1 & $75.5 \pm 0.57 \mathrm{~d}$ & $7.6 \pm 0.08 \mathrm{~d}$ & $28.0 \pm 1.02 \mathrm{e}$ & $1.08 \pm 0.01 \mathrm{~d}$ \\
A2B2 & $87.9 \pm 2.01 \mathrm{c}$ & $7.8 \pm 0.09 \mathrm{~d}$ & $28.2 \pm 0.87 \mathrm{e}$ & $1.41 \pm 0.02 \mathrm{a}$ \\
A2B3 & $87.7 \pm 1.17 \mathrm{c}$ & $8.2 \pm 0.08 \mathrm{c}$ & $33.3 \pm 0.31 \mathrm{~b}$ & $1.26 \pm 0.02 \mathrm{~b}$ \\
A2B4 & $91.3 \pm 0.78 \mathrm{ab}$ & $8.8 \pm 0.09 \mathrm{~b}$ & $30.6 \pm 0.53 \mathrm{~d}$ & $1.09 \pm 0.01 \mathrm{~d}$ \\
A3B1 & $41.6 \pm 1.37 \mathrm{~h}$ & $6.1 \pm 0.08 \mathrm{f}$ & $16.1 \pm 0.53 \mathrm{~g}$ & $0.49 \pm 0.02 \mathrm{~g}$ \\
A3B2 & $69.6 \pm 1.30 \mathrm{e}$ & $6.9 \pm 0.08 \mathrm{e}$ & $16.9 \pm 0.39 \mathrm{~g}$ & $0.64 \pm 0.03 \mathrm{f}$ \\
A3B3 & $62.4 \pm 1.57 \mathrm{~g}$ & $6.0 \pm 0.12 \mathrm{f}$ & $23.4 \pm 0.66 \mathrm{f}$ & $0.67 \pm 0.02 \mathrm{f}$ \\
A3B4 & $65.4 \pm 1.56 \mathrm{f}$ & $7.0 \pm 0.12 \mathrm{e}$ & $16.3 \pm 0.68 \mathrm{~g}$ & $0.75 \pm 0.02 \mathrm{e}$ \\
\hline
\end{tabular}

*A1, A2 and A3 are the three salinity levels of 0,50 and $100 \mathrm{mM} \mathrm{NaCl}$ respectively; B1, B2, B3 and B4 are the four molar mass ratios of $\mathrm{NaCl}$ and $\mathrm{CaCl}_{2}$ of $20: 0,20: 1,20: 2$ and $20: 3$ respectively. Means in the same column followed by the same letters do not differ statistically at the 0.05 probability level using AVOVA-protected Tukey's HSD test.

In the present study, all calcium amendments $(20: 1$, $20: 2,20: 3$ ) increased the emergence of castor bean (Table 3). We hypothesize that these beneficial effects could have three causes. First, germination can be promoted by appropriate calcium amendments that reduce saline effects. In a previous study, we found that exogenous calcium amendment at appropriate levels successfully mitigated the inhibitive effects of salinity and promoted the germination of castor bean in saline culture solutions ${ }^{14}$. High germination percentage and rapid germination are usually beneficial to the following emergence. Secondly, changes in the content and composition of many compounds in the seeds can be affected by the amendment of exogenous calcium and these changes play an important role in promoting emergence. During seed germination, calcium amendment can decrease the contents of soluble saccharides and quaternary ammonium compounds (QACs), and increase the contents of insoluble saccharides, proteins, and free amino acids. The increase in insoluble saccharides and free amino acids and decrease in soluble saccharides and QACs were found beneficial to germination and emergence ${ }^{21,31}$. Finally, supplemental $\mathrm{Ca}^{2+}$ amendment can also alleviate the inhibitive effects of salinity on radicle elongation by returning the hydraulic conductivity to its normal level ${ }^{32,33}$.

In the present study, salt stress reduced the early seedling growth of castor bean plants. Plant height, plant weight and leaf area were reduced significantly in the high-level salinity treatments without exogenous calcium amendment. The appearance of first leaf was also delayed in most treatments at high salinity level. This reduction in plant growth might be caused by toxic effects of ions, osmotic effect and an imbalance in the absorbance of essential mineral elements. These modes of action may 


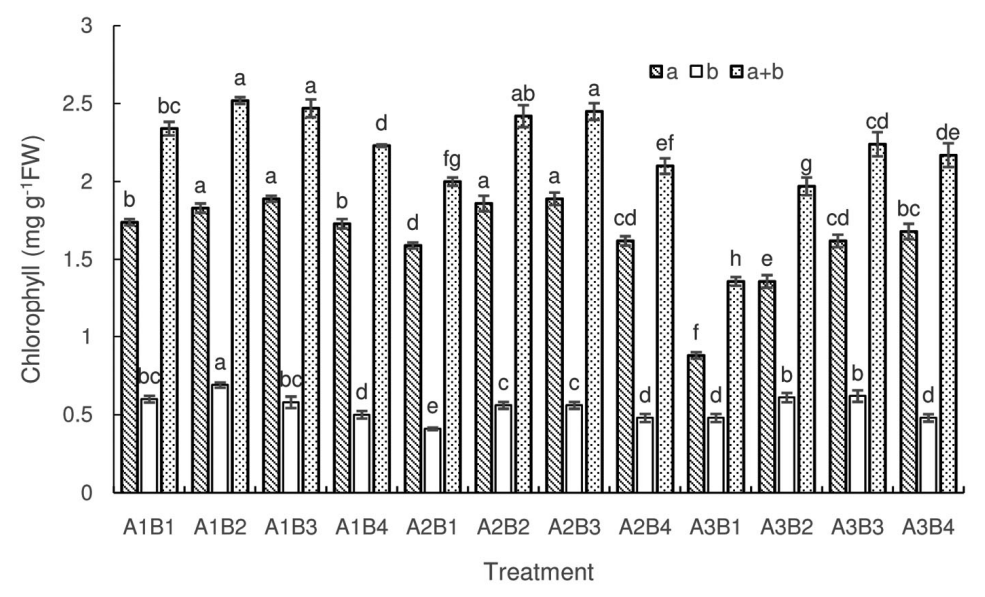

Figure 1. Chlorophyll $a, b$ and $a+b$ of the leaves of castor seedlings as influenced by different levels of salinity and external calcium amendment.

(a)

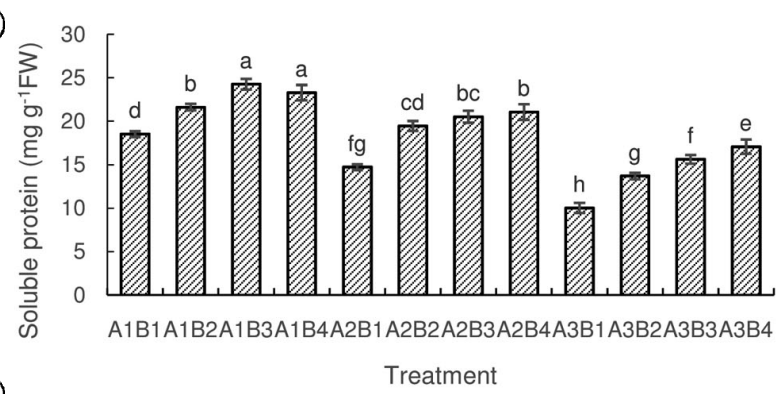

(b)

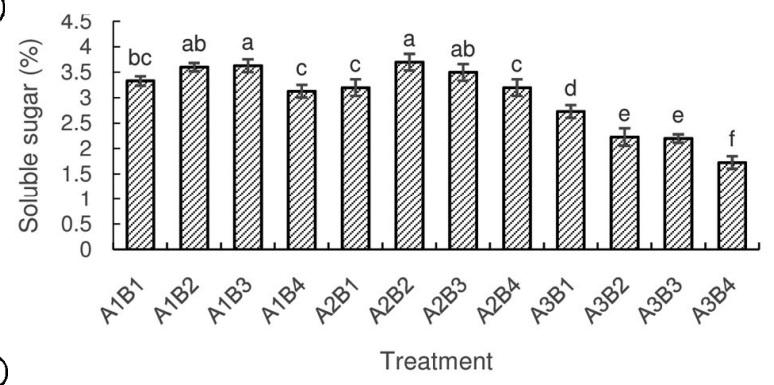

(c)

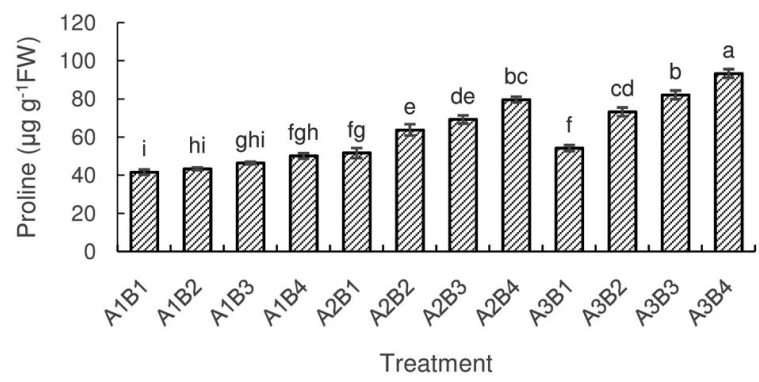

Figure 2. Soluble protein $(\boldsymbol{a})$, soluble sugar $(\boldsymbol{b})$ and proline $(\boldsymbol{c})$ of the leaves of castor seedlings as influenced by different levels of salinity and external calcium amendment.

operate at the cellular and tissue levels, and affect plant metabolism ${ }^{34,35}$. At the cellular level, water loss usually occurs in leaf mesophylls, and cell division and cell expansion rate are lowered under salinity stress conditions $^{36-38}$. At the organizational level, the expansion rate of leaf area is lowered or even halted by increased salt concentration $^{13}$. Apart from the reduction in leaf area, decreased content of chlorophyll and soluble protein and, reduced photosynthetic rate may also result in lowered plant growth ${ }^{35,39,40}$.

When plants are subjected to salinity stress, an increased concentration of calcium often can alleviate the inhibitive effects on growth. The ameliorating effects of calcium amendment at appropriate concentrations on seedling growth of castor plants were also observed in this study. However, Severino et al. ${ }^{41}$ reported that the existence of magnesium and calcium in irrigation water does not alleviate the toxic effects of sodium on the emergence and seedling growth of castor, safflower and cotton plants ${ }^{41}$. This difference might be due to the difference in the growing media and the demand for $\mathrm{Ca}^{2+}$ by the plants. In the present study, sand containing one-half Hoagland solution without $\mathrm{Ca}\left(\mathrm{NO}_{3}\right)_{2}$ was used as the growing medium, while in the study by Severino et al. ${ }^{41}$ the substrate was soil collected from an experimental farm with $2500 \mathrm{mg} \mathrm{kg}^{-1} \mathrm{Ca}^{2+}$. Although the underlying mechanism of calcium amendment on seedling growth is not fully understood, the mitigating effects of calcium are considered to involve aspects of ion exchange and membrane stabilization, signalling transduction, cell division and expansion, water transport and photosynthesis ${ }^{19}$. Calcium is easily transferred from membrane-binding sites by other positive ions such as $\mathrm{Na}$ and $\mathrm{K}$, and these displacements could be more severe when calcium availability is reduced. The displacement can be counteracted by increasing exogenous calcium concentration in seeding media. The increased calcium concentration can increase the uptake of calcium by reducing $\mathrm{Na}$ conductance and increasing $\mathrm{K}$ conductance through ion channels across membranes ${ }^{19,32,42,43}$. Apart from the direct effects of calcium on ionic migration, it also acts through a signalling pathway. With supplemental calcium, some proteins are produced which serve as a signalling pathway regulating $\mathrm{Na}$ and $\mathrm{K}$ selectivity and thereby alter $\mathrm{K} / \mathrm{Na}$ selectivity across the membranes ${ }^{44}$. The stress effects of $\mathrm{Na}$ on cell size, shape and production rate can also be mitigated by 


\section{RESEARCH ARTICLES}

supplemental calcium amendment. Cell size, cell volume, cell production and cell-wall biosynthesis rate are partially or fully restored to normal levels with supplemental calcium at appropriate concentrations ${ }^{45,46}$. Exogenous modification of calcium plays an important role in promoting water transport in plant tissues, thus preventing the decrease in hydraulic conductance of roots and leaves ${ }^{32}$. Supplementation with $\mathrm{Ca}^{2+}$ can improve the effects of salt on the production of certain substances in crop plants. In the present study, we observed that the production of soluble protein at the both salinity levels was promoted by the amendment of exogenous calcium. Soluble protein is the most important source of many enzymes related to physiological processes in crop plants. The increase in soluble protein is beneficial to the restoration of photosynthesis to normal levels ${ }^{47}$.

Proline is deemed to be a compatible solute participating in osmotic adjustment ${ }^{48}$. It can be used as an enzyme protector to stabilize the structure of organelles and macromolecules ${ }^{49}$. It also serves as a main repository of nitrogen and energy for utilization when exposed to salinity. In this study, salinity promoted the accumulation of proline. This may be due to the disruption of prolinerich proteins and new synthesis of amino acids and proline $\mathrm{e}^{50}$. We also found that the addition of $\mathrm{Ca}^{2+}$ increased the proline content. Calcium supplementation caused an increase in the accumulation of proline in salinized plants, which may be related to maintaining a more beneficial ratio of $\mathrm{K}^{+}$to $\mathrm{Na}^{+}$in plants ${ }^{51}$. Failure to maintain a good $\mathrm{K}^{+}: \mathrm{Na}^{+}$ratio can inhibit the function of enzymes, which conversely may prevent the synthesis of proline under low $\mathrm{Ca}^{2+}$ supply ${ }^{52}$. External $\mathrm{Ca}^{2+}$ has a profound effect on the selectivity of net $\mathrm{K}^{+}$to $\mathrm{Na}^{+}$(ref. 53). Due to supplemental $\mathrm{Ca}^{2+}$, significant enhancement in the accumulation of proline can mitigate $\mathrm{NaCl}$-induced growth inhibition through maintaining the selectivity of net $\mathrm{K}^{+}$to $\mathrm{Na}^{+}$.

We found that measurements of leaf area and chlorophyll had the most consistent response to calcium amendment treatments in this study. As these measures have been shown to be consistently correlated with plant health, vigour and growth potential, we propose that they are good measures for evaluation of calcium amendments.

Generally, calcium amendment is applied either through soil supplement or by foliar spray. Soil calcium supplement can play a relatively long-term role in mitigating the inhibitory effects of salinity. However, calcium can probably be more quickly absorbed by leaf mesophyll cells if foliar spray is done at appropriate concentrations. So calcium amendment through soil supplement and foliar spray could be combined to improve the mitigating effects on emergence and seedling growth of castor bean.

From this study, we can conclude that amendment of $20: 2$ has the best promotional effects under conditions of both low and moderate salinity. Although an amendment of $20: 3$ demonstrated some advantage at higher salinity level, results were inconsistent. However, this study was conducted in a controlled chamber and the growing medium used was one-half Hoagland solution without $\mathrm{Ca}\left(\mathrm{NO}_{3}\right)_{2}$. A field study is necessary to test the effects of calcium amendment in open field conditions.

\section{Conclusion}

By increasing salinity level from 0 to $100 \mathrm{mM} \mathrm{NaCl}$, emergence and seedling growth were significantly affected, with reduction in emergence, plant height, leaf area and physiological activities. Calcium amendment, especially the amendment of $20: 2$, mitigated the inhibitory effects of salinity on castor bean grown in $\mathrm{Ca}\left(\mathrm{NO}_{3}\right)_{2}$ free one-half Hoagland solution. However, a field study is needed to prove the promotional effects of calcium amendment under practical field conditions.

1. Munns, R., Comparative physiology of salt and water stress. Plant Cell Environ., 2002, 25, 239-250.

2. Munns, R. and Tester, M., Mechanisms of salinity tolerance. Annu. Rev. Plant Biol., 2008, 59, 651-681.

3. Kammann, C. I., Linsel, S., Johannes, W. and GöBling Koyro, H. W., Influence of biochar on drought tolerance of Chenopodium quinoa Willd and on soil-plant relations. Plant Soil, 2011, 345, 195-210.

4. Shrivastava, P. and Kumar, R., Soil salinity: a serious environmental issue and plant growth promoting bacteria as one of the tools for its alleviation. Saudi J. Biol. Sci., 2015, 22, 123-131.

5. Zhou, G. S., Ma, B. L., Xia, Y. R., Feng, C. N. and Qin, P., Culture of seashore mallow under different salinity levels using plastic nutrient-rich matrices and transplantation. Agron. J., 2010, 102, 395-402.

6. Zhou, G. S., Ma, B. L., Li, J., Feng, C., Lu, J. F. and Qin, P., Determining salinity threshold level for castor bean emergence and stand establishment. Crop Sci., 2010, 50, 2030-2036.

7. Li, G., Wan, S. W., Zhou, J., Yang, Z. Y. and Qin, P., Leaf chlorophyll fluorescence, hyperspectral reflectance, pigments content, malondialdehyde and proline accumulation responses of castor bean (Ricinus communis L.) seedlings to salt stress levels. Ind. Crops Prod., 2010, 31, 13-19.

8. Quijano-Guerta, C. and Kirk, G. J. D., Tolerance of rice germplasm to salinity and other soil chemical stresses in tidal wetlands. Field Crops Res., 2002, 76, 111-121.

9. Talaat, N. B., Ghoniem, A. E., Abdelhamid, M. T. and Shawky, B. T., Effective microorganisms improve growth performance, alter nutrients acquisition and induce compatible solutesaccumulation in common bean (Phaseolus vulgaris L.) plants subjected to salinity stress. Plant Growth Regul., 2015, 75, 281-295.

10. Lolaei, A., Effect of calcium chloride on growth and yield of tomato under sodium chloride stress. J. Ornament. Horticult. Plants, 2012, 2, 155-160.

11. Joshi, S. V., Patel, N. T., Pandey, I. B. and Pandey, A. N., Effect of supplemental $\mathrm{Ca}^{2+}$ on $\mathrm{NaCl}$-stressed castor plants (Ricinus communis L.). Acta Bot. Croat, 2012, 71, 13-29.

12. Sivritepe, N., Sivritepe, H. O. and Eris, A., The effects of $\mathrm{NaCl}$ priming on salt tolerance in melon seedlings grown under saline conditions. Sci. Hortic., 2003, 97, 229-237.

13. Zhou, G. S. and Ma, B. L., Calcium amendment affects germination and early seedling growth of sweet sorghum under saline conditions. Agric. Sci. Technol., 2012, 13, 2538-2543.

14. Zhou, G., Liu, G., An, L., Gao, H., Tong, C. and Lu, S., Water uptake and germination of castor seeds as influenced by salinity 
and foreign calcium amendment. J. Anhui Agric. Sci., 2012, 40 , 16983-16986 (in Chinese with English abstract).

15. Marschner, P., Mineral Nutrition of Higher Plants, Academic Press, London, UK, 2012, 3rd edn.

16. Hirschi, K. D., The calcium conundrum. Both versatile nutrient and specific signal. Plant Physiol., 2004, 136, 2438-2442.

17. Grattan, S. R. and Grieve, C. M., Salinity-mineral nutrient relations in horticultural crops. Sci. Hortic., 1999, 78, 127-157.

18. Gao, H., Jia, Y. X., Guo, S. R., Lv, G. Y., Wang, T. and Li, J., Exogenous calcium affects nitrogen metabolism in root-zone hypoxia-stressed muskmelon roots and enhances short-term hypoxia tolerance. J. Plant Physiol., 2011, 168, 1217-1225.

19. Rahman, A., Nahar, K., Hasanuzzaman, M. and Fujita, M., Calcium supplementation improves $\mathrm{Na}^{+} / \mathrm{K}^{+}$ratio, antioxidant defense and glyoxalase systems in salt-stressed rice seedlings. Front Plant Sci., 2016; https://doi.org/10.3389/fpls.2016.00609.

20. Al-Whaibi, M. H., Siddiqui, M. H. and Basalah, M. O., Salicylic acid and calcium-induced protection of wheat against salinity. Protoplasma, 2012, 249, 769-768.

21. Hamada, A. M., Alleviation of the adverse effects of $\mathrm{NaCl}$ on germination of maize grains by calcium. Biol. Planta, 1994, 36, 623-627.

22. Kazemi, M., Foliar application of salicylic acid and calcium on yield, yield component and chemical properties of strawberry. Bull. Environ. Pharmacol. Life Sci., 2013, 2, 19-23.

23. Abbasi, N. A., Zahoor, M., Khan, H. A. and Qureshi, A. A., Effect of encapsulated calcium carbide application at different growth stages on potato (Solanum tuberosum L.) growth, yield and tuber quality. Pak. J. Bot., 2012, 44(4), 1543-1550.

24. Wintermans, J. F. and De Mots, A., Spectrophotometric characteristics of chlorophylls $a$ and $b$ and their pheophytins in ethanol. Biochim. Biophys. Acta, 1965, 109, 448-453.

25. Haslemore, R. M. and Roughan, P. G., Rapid chemical analysis of some plant constituents. J. Food Agric., 1976, 27, 1171-1178.

26. Bradford, M. M., A rapid and sensitive method for the quantification of microgram quantities of protein utilizing the principle of protein-dye binding. Anal. Biochem., 1976, 72, 248-254.

27. Bates, L., Waldren, R. P. and Teare, I. D., Rapid determination of free proline for water-stress studies. Plant Soil, 1973, 39, 205-207.

28. Tang, Q. Y. and Feng, M. G., Practical Statistics and DPS Data Processing System, China Agricultural Press, Beijing, China, 1997 (in Chinese).

29. Wang, X. C. et al., Comparative proteomics of Thellungiella halophila leaves from plants subjected to salinity reveals the importance of chloroplastic starch and soluble sugars in halophyte salt tolerance. Mol. Cell. Proteomics, 2013, 12, 2174-2195.

30. Garg, B. K., Vyas, S. P., Kathju, S., Lahiri, A. N., Mali, P. C. and Sharma, P. C., Salinity-fertility interaction on growth, mineral composition and nitrogen metabolism of Indian mustard. J. Plant Nutr., 1993, 16, 1637-1650.

31. Sneha, S., Rishi, A., Dadhich, A. and Chandra, S., Effect of salinity on seed germination, accumulation of proline and free amino acid in Pennisetum glaucum (L.) R. Br. Pak. J. Biol. Sci., 2013, 16, 877-881

32. Cramer, G. R., Kinetics of maize leaf elongation. II. Response of a Na-excluding cultivar and a Naincludingcultivar to varying $\mathrm{Na}$ : Ca salinities. J. Exp. Bot., 1992, 43, 857-864.

33. Shaikh, F., Gul, B., Li, W., Liu, X. and Khan, M. A., Effect of calcium and light on the germination of Urochondra setulosa under different salts. J. Zhejiang Univ. Sci. B, 2007, 8, 20-26.

34. Arora, A., Sairam, R. K. and Srivastva, G. C., Oxidative stress and antioxidative systems in plants. Curr. Sci., 2002, 82, 1227-1238.

35. Garg, B. K. and Gupta, I. C., Saline Wastelands Environment and Plant Growth, Scientific Publishers, Jodhpur, 1997, p. 287.

36. Ratnakar, A. and Rai, A., Effect of sodium chloride salinity on seed germination and early seedling growth of Trigonella foenumgraecum 1. Var. PEB. Octa J. Environ. Res., 2013, 1, 304-309.
37. Tsegay, B. A. and Gebreslassie, B., The effect of salinity $(\mathrm{NaCl})$ on germination and early seedling growth of Lathyrus sativus and Pisum sativum var. abyssinicum. Afr. J. Plant Sci., 2014, 8, 225231.

38. Ehret, D. L., Redmann, R. E., Harvey, B. L. and Cipywnyk, A., Salinity-induced calcium deficiencies in wheat and barley. Plant Soil, 1990, 128, 143-151.

39. Parida, A. K. and Das, A. B., Salt tolerance and salinity effects on plants. Ecotoxicol. Environ. Safe., 2005, 60, 324-349.

40. Rahdari, P., Tavakoli, S. and Hosseini, S. M., Studying of salinity stress effect on germination, proline, sugar, protein, lipid and chlorophyll content in purslane (Portulaca oleracea L.) leaves. $J$. Stress Physiol. Biochem., 2012, 8, 182-193.

41. Severino, L. S., Lima, R. L. S., Castillo, N., Lucena, A. M. A., Auld, D. L. and Udeigwe, T. K., Calcium and magnesium do not alleviate the toxic effect of sodium on the emergence and initial growth of castor, cotton, and safflower. Ind. Crops Prod., 2014, 57, 90-97.

42. Bañuls, J. and Primo-Millo, E., Effects of chloride and sodium on gas exchange parameters and water relations of citrus plants. Physiol. Plant, 1992, 86, 115-123.

43. Roberts, S. K. and Tester, M., Permeation of $\mathrm{Ca}^{2+}$ and monovalent cations through an outwardly rectifying channel in maize root stelar cells. J. Exp. Bot., 1997, 48, 839-846.

44. Liu, J. P. and Zhu, J. K., A calcium sensor homolog required for plant salt tolerance. Science, 1998, 280, 1943-1945.

45. Zidan, I., Azaizeh, H. and Neumann, P. M., Does salinity reduce growth in maize root epidermal cells by inhibiting their capacity for cell wall acidification? Plant Physiol., 1990, 93, 7-11.

46. Azaizeh, H., Gunse, B. and Steudle, E., Effects of $\mathrm{NaCl}$ and $\mathrm{CaCl}_{2}$ on water transport across root cells of maize (Zea mays L.) seedlings. Plant Physiol., 1992, 99, 886-894.

47. Li, J., Responses of castor plant to exogenous calcium amendment at seedling stage under saline soil conditions. Master thesis, The School of Agronomy, Yangzhou University, China, 2011.

48. Azooz, M. M., Shadab, M. A. and Abdel-Latef, A. A., The accumulation and compartmentation of proline in relation to salt tolerance of three sorghum cultivars. Indian J. Plant Physiol., 2004, 9, $1-8$.

49. Girija, C., Smith, B. N. and Swamy, P. M., Interactive effects of sodium chloride and calcium chloride on the accumulation of proline and glycinebetaine in peanut (Arachis hypogaea L.). Environ. Exp. Bot., 2002, 47, 1-10.

50. Jun, H. R., Adam, L. H., Rozwadowski, K. L., Hammerlineli, J. L., Keller, W. A. and Selvaraj, G., Genetic engineering of glycine betain production towards enhancing stress tolerance in plants. Plant Physiol., 2000, 12, 747-756.

51. Arshi, A., Abdin, M. Z. and Iqbal, M., Ameliorative effects of $\mathrm{CaCl}_{2}$ on growth, ionic relations and proline content of senna under salinity stress. J. Plant Nutr., 2005, 28, 101-125.

52. Greenway, H. and Munns, R., Mechanism of salt tolerance in nonhalophytes. Annu. Rev. Plant Physiol., 1980, 31, 149-190.

53. Zhong, H. and Lauchli, A., Spatial distribution of solutes, K, Na, $\mathrm{Ca}$ and their deposition rates of the growth zone of primary cotton roots: effects of $\mathrm{NaCl}$ and $\mathrm{CaCl}_{2}$. Planta, 1994, 194, 34-41.

ACKNOWLEDGEMENTS. This study was supported in part by the Jiangsu Provincial Key R\&D Program (BE2016345), Jiangsu Provincial Agricultural Innovation Fund (CX16(1005)), the Priority Academic Program Development of Jiangsu Higher Education Institution, and Natural Science Foundation of Jiangsu Higher Education Institutions of China (No. 17KJB210008).

Received 7 December 2018; accepted 14 February 2019

doi: $10.18520 / \mathrm{cs} / \mathrm{v} 116 / \mathrm{i} 12 / 2028-2035$ 